\title{
Four new myxozoans (Myxosporea: Bivalvulida) from intertidal fishes along the south coast of Africa
}

\author{
Cecilé C. Reed ${ }^{1,2}$, Linda Basson ${ }^{1}$, Liesl L. Van As ${ }^{1}$ and Iva Dyková ${ }^{3}$ \\ ${ }^{1}$ Department of Zoology and Entomology, University of the Free State, P.O. Box 339, Bloemfontein, 9300, South Africa; \\ ${ }^{2}$ Current address: Department of Zoology, University of Cape Town, Private Bag X3, Rondebosch, 7701, South Africa; \\ ${ }^{3}$ Institute of Parasitology, Biology Centre, Academy of Sciences of the Czech Republic, Branišovská 31, 37005 České \\ Budějovice, Czech Republic
} Key words: Myxozoa, marine fishes, Ceratomyxa dehoopi, Ceratomyxa cottoidii, Ceratomyxa honckenii,
Henneguya clini, South Africa

\begin{abstract}
Current records of marine myxozoans from the coast of Africa are limited to the descriptions of 52 species from mostly Senegal, with a few from Tunisia and southern Africa. Between 1998 and 2000 several intertidal fishes from the southern Cape coast of South Africa were examined for the presence of myxozoan infections. Three new species, Ceratomyxa dehoopi sp. n., C. cottoidii sp. n. and C. honckenii sp. n. were identified from the gall bladders of Clinus superciliosus L., C. cottoides Valenciennes and Amblyrhynchotes honckenii (Bloch), respectively. A fourth new species Henneguya clini sp. n. was also identified from the gills and gill arches of C. superciliosus.
\end{abstract}

Very little is known about the distribution and diversity of marine myxozoans along Africa's coastline. Research on these parasites is restricted to the description of 52 species from the entire extent of the African coastline, the majority of which were described from Senegal. Early records of myxozoan infections in African marine fishes appeared from southern Africa between 1919 and 1979. Fantham $(1919,1930)$ recorded several myxozoan species from the bile of a number of intertidal fishes along the Cape south coast. Gilchrist (1924) described Chloromyxum thyrsites Gilchrist, 1924 from the muscles of Cape Sea fish, or "snoek", which is a species well-known around the world today as the notorious Kudoa thyrsites (Gilchrist, 1924). Subsequent to Gilchrist's (1924) description, Davies and Beyers (1947) recorded the presence of $K$. thyrsites in some of the South African trawled fishes and during the 1970s Dubina and Isakov (1976), Gaevskaya and Kovaleva (1979) as well as Schulman et al. (1979) described several new myxozoan species from deep sea fish off the coast of southern Africa.

After these initial myxozoan publications from southern Africa, approximately 15 years passed before a number of species descriptions started to appear from the North-West coast of Africa (Bahri et al. 1995, 1996, Bahri and Marqués 1996, Kpatcha et al. 1996a, b, 1997, 1999, Fall et al. 1997, Faye et al. 1997, 1999, Diebakate et al. 1999). Subsequent to these publications Ali (2000) described Ortholinea basma Ali, 2000 from the gall bladder of the agile klipfish Clinus agilis, from the West coast of South Africa.

This paper represents the first publication on the occurrence of myxozoans infecting intertidal fishes from the De Hoop Nature Reserve along the south coast of South Africa. Three new species of the genus Ceratomyxa Thélohan, 1892, are described from the gall bladders of Clinus superciliosus L., C. cottoides Valenciennes and Amblyrhynchotes honckenii (Bloch), respectively. A fourth new species from the genus Henneguya Thélohan, 1892 is described from the gills and gill arches of $C$. superciliosus.

\section{MATERIALS AND METHODS}

A total of 14 Amblyrhynchotes honckenii, 44 Clinus cottoides and 131 C. superciliosus were collected on several fieldtrips to the De Hoop Nature Reserve and Jeffrey's Bay, both of which are situated along the south coast of South Africa. Fishes were collected from intertidal rock pools using small hand nets and hand lines. Captured fish were identified using Branch et al. (1994) and subsequently euthanized using the anaesthetic Benzocaine (ethyl-4-aminobenzoate) $\left(2.5 \times 10^{5}\right.$ $\mathrm{g} / \mathrm{l})$, measured and examined for the presence of myxosporean infections. Squash preparations of the gall bladder contents were made and live mature myxosporean spores and plasmodia detected were transported to the laboratory, using sealed haematocrit tubes. Live spores and plasmodia were photographed on a layer of $0.5 \%$ non-nutrient agar, using an Axiophot microscope with differential interference contrast. The live spores were measured according to the guidelines provided by Lom and Arthur (1989). Minimum and maximum values of spore measurements are provided in micrometres $(\mu \mathrm{m})$, followed in parentheses by the arithmetic mean and standard deviation. Spores were measured from several infected host specimens. Formalin-fixed spores were dehydrated, critical point dried, coated with gold and viewed using a JEOL Winsem JSM 6400 at 5 or $10 \mathrm{kV}$, respectively. Tissue 
samples of gall bladder and gills containing plasmodia and spores were prepared for transmission electron microscopy using standard techniques. Tissue samples of gall bladder, liver and kidney containing plasmodia and spores were fixed in Davidson's solution and prepared for histological sectioning using standard techniques. Sections cut at $7 \mu \mathrm{m}$ were stained using haematoxylin and eosin (H\&E) and Giemsa stain.

\section{RESULTS AND DISCUSSION}

Ceratomyxa dehoopi $\mathrm{sp} . \mathrm{n}$.

Figs. 1-9, 12, 17-19

Spores ( $\mathrm{n}=38$ live spores): Mature spores transversely elongate and narrowly crescent-shaped with slightly convex anterior and concave posterior, 4.0-5.5 $(4.5 \pm 0.5) \mu \mathrm{m}$ long $\times 12.0-17.5(15.4 \pm 1.4) \mu \mathrm{m}$ wide.
Spore shell valves equal in length, with smooth surface, each tapering to a rounded end. Sutural line thin and straight. Two spherical to ovoid polar capsules situated on either side of sutural line, 2.0-3.0 (2.7 \pm 0.3$) \mu \mathrm{m}$ long $\times 2.0-2.5(2.1 \pm 0.2) \mu \mathrm{m}$ wide. Number of coils per polar filament not observed. A single binucleate sporoplasm almost filling entire spore cavity and containing a single, small iodinophilous vacuole.

Vegetative stages: Plasmodia coelozoic and mostly spherical, transparent, with numerous refractile granules and inner generative cells, often with long extensions connecting disporous trophozoites. Some appeared attached to gall bladder epithelium. These varied greatly in size $(5-20 \mu \mathrm{m})$ and shape.
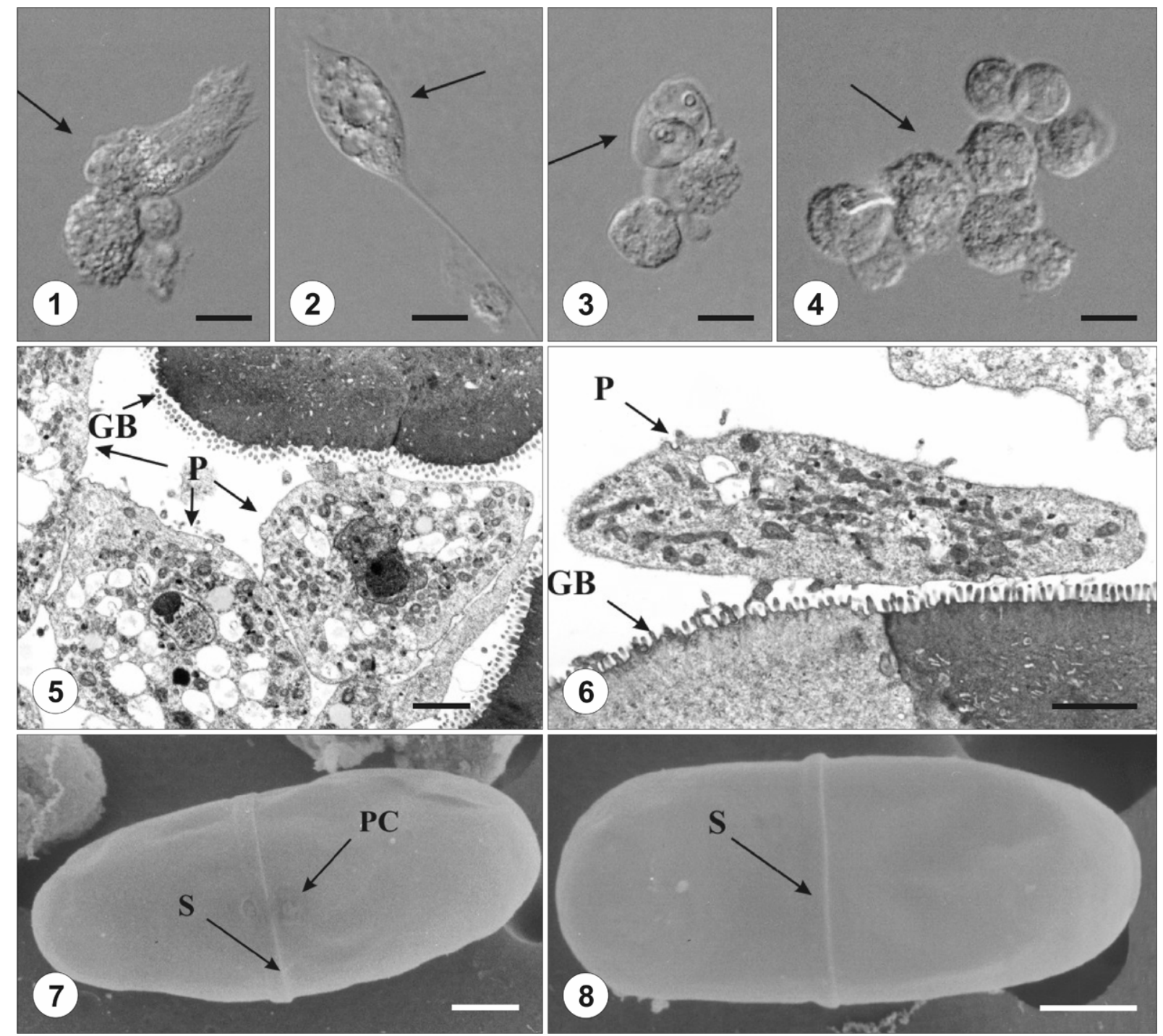

Figs. 1-8. Light micrographs, transmission electron micrographs and scanning electron micrographs of Ceratomyxa dehoopi sp. n. infecting the gall bladder of Clinus superciliosus from the Cape south coast of South Africa. Figs. 1-4. Live plasmodia (arrows). Figs. 5, 6. Plasmodia (P) seen associated with the gall bladder epithelium (GB). Figs. 7, 8. Spores showing the sutural ridge (S) and polar filament discharge ducts (PC). Scale bars: Figs. $1-4=10 \mu \mathrm{m}$; Figs. 5, $6=1 \mu \mathrm{m}$; Figs. 7, $8=2 \mu \mathrm{m}$. 

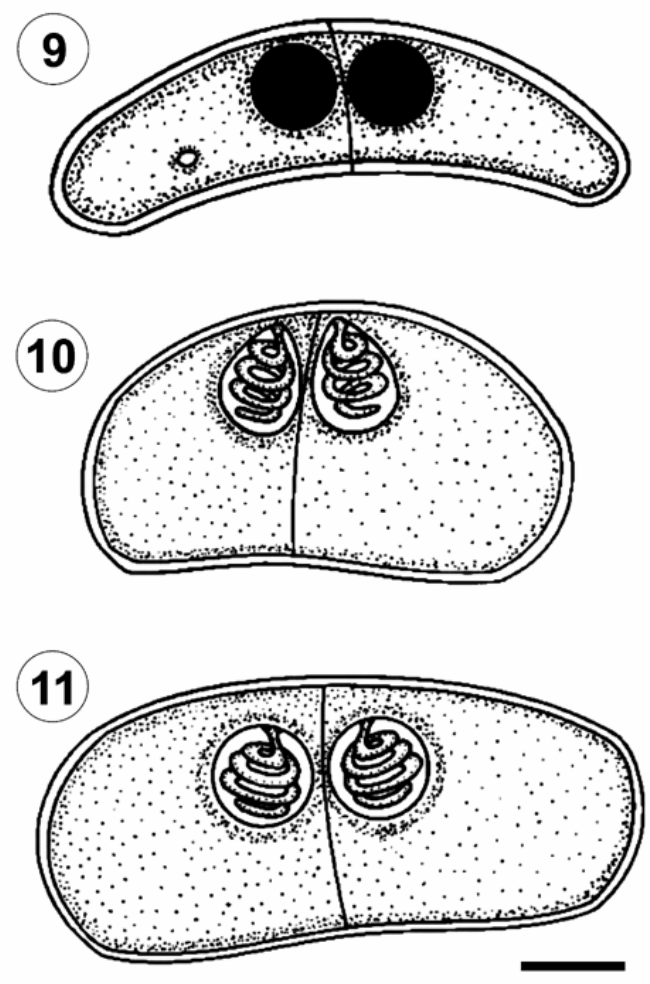

Figs. 9-11. Line drawings of Ceratomyxa Thélohan, 1892 species infecting the gall bladders of intertidal fishes along the Cape south coast, South Africa. Fig. 9. Ceratomyxa dehoopi sp. n. from Clinus superciliosus (polar capsules represented by black circles as polar filaments could not be seen). Fig. 10 . Ceratomyxa cottoidii sp. n. from C. cottoides. Fig. 11. Ceratomyxa honckenii sp. n. from Amblyrhynchotes honckenii. Scale bar (Figs. 9-11) $=10 \mu \mathrm{m}$.

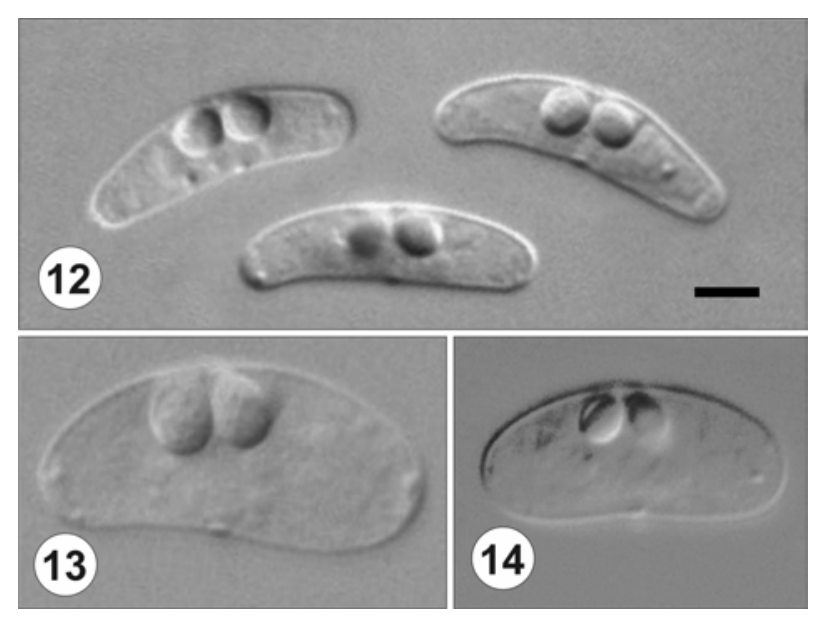

Figs. 12-14. Light micrographs of live spores of Ceratomyxa Thélohan, 1892 species infecting the gall bladders of intertidal fishes along the Cape south coast, South Africa. Fig. 12. Ceratomyxa dehoopi sp. n. from Clinus superciliosus. Fig. 13. Ceratomyxa cottoidii sp. n. from C. cottoides. Fig. 14. Ceratomyxa honckenii sp. n. from Amblyrhynchotes honckenii. Scale bar (Figs. 12-14) $=10 \mu \mathrm{m}$.
T y p e h o s t: Clinus superciliosus (Linnaeus, 1758) - endemic to southern Africa from the coast of Namibia $\left(19^{\circ} \mathrm{S}\right)$ to the Kei River mouth on the southeast coast of South Africa.

T y p e 1 o c a 1 i t y : De Hoop Nature Reserve $\left(34^{\circ} 28^{\prime} \mathrm{S}\right.$, $\left.20^{\circ} 30^{\prime} \mathrm{E}\right)$, South Africa.

O t h e r 1 o c a 1 i t i e s : Jeffrey's Bay $\left(34^{\circ} 2.2^{\prime} \mathrm{S}\right.$, $\left.24^{\circ} 56.5^{\prime} \mathrm{E}\right)$, South Africa.

Site of infection: Gall bladder and bile ducts.

P r e v a 1 e n c e : De Hoop Nature Reserve, 83\% (76/92); Jeffrey's Bay, 92\% (35/38).

E t y m o 1 o g y : Named after the original collection locality of the type host.

P h o t o - r e f e r e n c e : Deposited in the National Museum Bloemfonteins' Parasite Collection; reference number: NMBP 299.

\section{Remarks}

In Africa only nine Ceratomyxa species have been described from marine fish hosts (Dubina and Isakov 1976, Gaevskaya and Kovaleva 1979, Kpatcha, et al. 1996b) (see Table 1). The majority of these were described from fishes collected off the coast of Senegal by Kpatcha et al. (1996b). Ceratomyxa dehoopi shows morphological similarities with only two of these species. Ceratomyxa fistulariae Kpatcha, Diebakate, Faye et Toguebaye, 1996, described from the bile ducts of Fistularia petimba in Senegal by Kpatcha et al. (1996b), is similar in general spore shape, but has a much greater spore width than $C$. dehoopi (Table 2). Comparatively, C. truncata Thélohan, 1895 found infecting the bile ducts of Sardinella madarensis also in Senegal by Kpatcha et al. (1996b), has a much broader spore (Table 2 ), is more strongly arched and has a prominent sutural ridge, unlike the smaller less arched spores of $C$. dehoopi. Compared with species from around the world, C. dehoopi resembles C. arripica $\mathrm{Su}$ et White, 1994 described from the gall bladder of Arripis trutta in Tasmania, Australia by Su and White (1994). The spores of Ceratomyxa dehoopi are, however, broader and do not have an almost straight posterior end, as in the case of C. arripica. Ceratomyxa dehoopi is most similar to $C$. sparusaurati Sitjà-Bobadilla, Palenzuela et ÁlvarezPellitero, 1995 described from the gall bladder of Sparus aurata in Spain by Sitjà-Bobadilla et al. (1995). The spore dimensions are very similar, but the spores of $C$. sparusaurati have a slightly more convex anterior and concave posterior end, compared with the more straightened spores of $C$. dehoopi.

\section{Pathogenicity}

Histological sections and transmission electron micrographs of infected gall bladders of Clinus superciliosus revealed that the plasmodia of Ceratomyxa dehoopi appear attached to the gall bladder epithelium (Figs. 5, 6, 17-19). A similar observation was noted by Alvarez-Pellitero and Sitjà-Bobadilla (1993) working on Ceratomyxa labracis and $C$. diplodae that parasitize the Mediterranean sea bass Dicentrarchus labrax. In both 
Table 1. Ceratomyxa Thélohan, 1892 species described from marine fishes along the coast of Africa. Key to references: 1 Dubina and Isakov (1976); 2 - Gaevskaya and Kovaleva (1979); 3 - Kpatcha et al. (1996b).

\begin{tabular}{|c|c|c|c|c|}
\hline Species & Hosts & Organ & Country & Reference \\
\hline $\begin{array}{l}\text { Ceratomyxa acanthuri Kpatcha, Diebakate, } \\
\text { Faye et Toguebaye, } 1996\end{array}$ & Acanthurus monroviae & gall bladder & Senegal & 3 \\
\hline $\begin{array}{l}\text { Ceratomyxa australis Gaevskaya et Kovaleva, } \\
1979\end{array}$ & Trachurus trachurus capensis & gall bladder & Namibia & 2 \\
\hline $\begin{array}{l}\text { Ceratomyxa fistulariae Kpatcha, Diebakate, } \\
\text { Faye et Toguebaye, } 1996\end{array}$ & Fistularia petimba & gall bladder & Senegal & 3 \\
\hline $\begin{array}{l}\text { Ceratomyxa lagocephali Kpatcha, Diebakate, } \\
\text { Faye et Toguebaye, } 1996\end{array}$ & Lagocephalus laevigatus & gall bladder & Senegal & 3 \\
\hline Ceratomyxa schulmani Dubina et Isakov, 1976 & Alepocephalus australis & gall bladder & South Africa & 1 \\
\hline $\begin{array}{l}\text { Ceratomyxa syacii Kpatcha, Diebakate, Faye } \\
\text { et Toguebaye, } 1996\end{array}$ & Syacium micrurum & gall bladder & Senegal & 3 \\
\hline $\begin{array}{l}\text { Ceratomyxa trachinocephali Kpatcha, } \\
\text { Diebakate, Faye et Toguebaye, } 1996\end{array}$ & Trachinocephalus myops & gall bladder & Senegal & 3 \\
\hline $\begin{array}{l}\text { Ceratomyxa trichiuri Kpatcha, Diebakate, Faye } \\
\text { et Toguebaye, } 1996\end{array}$ & Trichiurus lepturus & gall bladder & Senegal & 3 \\
\hline Ceratomyxa truncata Thélohan, 1895 & $\begin{array}{l}\text { Sardinella maderensis, } \\
\text { S. aurita }\end{array}$ & gall bladder & Senegal & 3 \\
\hline Ceratomyxa dehoopi $\mathrm{sp} . \mathrm{n}$. & Clinus superciliosus & $\begin{array}{l}\text { gall bladder } \\
\text { and liver }\end{array}$ & South Africa & present study \\
\hline Ceratomyxa cottoidii $\mathrm{sp} . \mathrm{n}$. & Clinus cottoides & gall bladder & South Africa & present study \\
\hline Ceratomyxa honckenii sp. $\mathrm{n}$. & Amblyrhynchotes honckenii & gall bladder & South Africa & present study \\
\hline
\end{tabular}

Table 2. Spore measurements (in $\mu \mathrm{m}$ ) of African marine Ceratomyxa Thélohan, 1892 species, including those from the present study. Key: $\mathrm{np}$ - not provided in original description; PC - polar capsule; * - species has both spherical and pyriform polar capsules. Key to references: 1 - Dubina and Isakov (1976); 2 - Gaevskaya and Kovaleva (1979); 3 - Kpatcha et al. (1996b).

\begin{tabular}{|c|c|c|c|c|c|}
\hline Species & Spore length & Spore width & PC length & PC width & Reference \\
\hline Ceratomyxa acanthuri & $\begin{array}{l}10.54 \pm 0.8 \\
(10.0-12.0)\end{array}$ & $\begin{array}{l}16.57 \pm 0.9 \\
(16.0-18.0)\end{array}$ & $\begin{array}{l}2.75 \pm 0.6 \\
(2.0-3.20)\end{array}$ & $\mathrm{np}$ & 3 \\
\hline Ceratomyxa australis & $4.0-5.3$ & $13.3-15.0$ & $2.0-2.6$ & 1.3 & 2 \\
\hline \multirow[t]{2}{*}{ Ceratomyxa fistulariae* } & $\begin{array}{l}10.25 \pm 0.6 \\
(10.0-12.0)\end{array}$ & $\begin{array}{l}39.64 \pm 0.56 \\
(38.8-40.0)\end{array}$ & $\begin{array}{l}5.21 \pm 0.5 \\
(4.5-5.5) \\
\text { in diameter }\end{array}$ & $\mathrm{np}$ & 3 \\
\hline & & & $\begin{array}{l}5.15 \pm 0.38 \\
(4.5-6.0)\end{array}$ & $\begin{array}{l}4.21 \pm 0.41 \\
(4.0-4.5)\end{array}$ & \\
\hline Ceratomyxa lagocephali & $\begin{array}{l}21.68 \pm 0.6 \\
(20.0-22.5)\end{array}$ & $\begin{array}{l}9.28 \pm 0.4 \\
(9.0-10.50)\end{array}$ & $\begin{array}{l}4.29 \pm 0.48 \\
(3.5-4.5) \\
\text { in diameter }\end{array}$ & $\mathrm{np}$ & 3 \\
\hline Ceratomyxa schulmani & 17 & 120 & 11.0 & 10.0 & 1 \\
\hline Ceratomyxa syacii & $\begin{array}{l}23.0 \pm 0.9 \\
(22.5-25.0)\end{array}$ & $\begin{array}{l}23.55 \pm 0.9 \\
(22.5-25.0)\end{array}$ & $\begin{array}{l}1.87 \pm 0.1 \\
(1.5-2.0) \\
\text { in diameter }\end{array}$ & $\mathrm{np}$ & 3 \\
\hline Ceratomyxa trachinocephali & $\begin{array}{l}11.5 \pm 0.8 \\
(10-12)\end{array}$ & $\begin{array}{l}49.66 \pm 0.7 \\
(48-50)\end{array}$ & $\begin{array}{l}2.7 \pm 0.4 \\
(2.0-3.0) \\
\text { in diameter }\end{array}$ & $\mathrm{np}$ & 3 \\
\hline Ceratomyxa. trichiuri & $\begin{array}{l}10.62 \pm 0.9 \\
(10.0-12.0)\end{array}$ & $\begin{array}{l}99.2 \pm 0.9 \\
(98.0-100.0)\end{array}$ & $\begin{array}{l}4.85 \pm 0.2 \\
(4.5-5.0) \\
\text { in diameter }\end{array}$ & $\mathrm{np}$ & 3 \\
\hline Ceratomyxa truncata & $\begin{array}{l}6.08 \pm 0.16 \\
(5.0-7.0)\end{array}$ & $\begin{array}{l}26.05 \pm 0.7 \\
(25.5-27.0)\end{array}$ & $\begin{array}{l}2.17 \pm 0.1 \\
(2.0-2.25) \\
\text { in diameter }\end{array}$ & $\mathrm{np}$ & 3 \\
\hline Ceratomyxa dehoopi sp. $\mathrm{n}$. & $\begin{array}{l}4.0-5.5 \\
(4.5 \pm 0.5)\end{array}$ & $\begin{array}{l}12.0-17.5 \\
(15.4 \pm 1.4)\end{array}$ & $\begin{array}{l}2.0-3.0 \\
(2.7 \pm 0.3)\end{array}$ & $\begin{array}{l}2.0-2.5 \\
(2.1 \pm 0.2)\end{array}$ & present study \\
\hline Ceratomyxa cottoidii $\mathrm{sp} . \mathrm{n}$. & $\begin{array}{l}6.5-8.0 \\
(7.1 \pm 0.6)\end{array}$ & $\begin{array}{l}17.0-22.0 \\
(18.2 \pm 1.7)\end{array}$ & $\begin{array}{l}2.3-3.0 \\
(2.7 \pm 0.4)\end{array}$ & $\begin{array}{l}2.0-3.0 \\
(2.4 \pm 0.4)\end{array}$ & present study \\
\hline Ceratomyxa honckenii sp. $\mathrm{n}$. & $\begin{array}{l}7.5-8.0 \\
(7.8 \pm 0.3)\end{array}$ & $\begin{array}{l}18.0-21.0 \\
(19.0 \pm 1.4)\end{array}$ & $\begin{array}{l}3.0-3.2 \\
(3.1 \pm 0.08)\end{array}$ & $\begin{array}{l}3.0-3.1 \\
(3.0 \pm 0.04)\end{array}$ & present study \\
\hline
\end{tabular}


wild and cultured conditions trophozoites appeared to line the gall bladder epithelium frequently, closely attached to the cell surface and even forming invaginations in it. Histopathological damage to the gall bladder of the infected fish might include vacuolation, deformation and even necrosis of epithelial cells (AlvarezPellitero and Sitjà-Bobadilla 1993).

In many cases the livers of infected $C$. superciliosus individuals were very light in colour and the bile appeared thick, opaque and dark green. Histological sections of liver showed that plasmodial stages of $C$. dehoopi develop mostly in the intra- but also in the extrahepatic bile ducts. The masses of spores appear to cause severe obstruction in the bile ducts and in the infected specimens the bile ducts were all distended and packed full with plasmodial stages and developing spores (Figs. 17-19). It is possible that the normal bile drainage of the liver was affected due to the extremely reduced diameter of the lumen. Interestingly, a regular centripetal arrangement of the long axis of the spores was observed in the spores maturing in the plasmodial stages (Fig. 19). Thickening and inflammation of the subepithelial connective tissue and damage to the neighbouring pancreatic tissue might also occur. In other ceratomyxoses, spread of the parasites to other organs was observed in very intense infections and stress situations, such as starvation (Sitjà-Bobadilla et al. 1995).

\section{Ceratomyxa cottoidii $\mathrm{sp}$. $\mathrm{n}$.}

Figs. 10, 13

Spores $(n=20$ live spores): Mature spores broadly elliptical to crescent-shaped with rounded convex anterior and almost straight posterior, 6.5-8.0 (7.0 \pm 0.6$)$ $\mu \mathrm{m}$ long $\times 17.0-22.0(18.2 \pm 1.7) \mu \mathrm{m}$ wide. Shell valves smooth with one occasionally tapering to a greater degree than the other. Sutural line straight with two spherical to ovoid polar capsules situated medially. Polar capsules 2.3-3.0 (2.7 \pm 0.4$) \mu \mathrm{m}$ long $\times 2.0-3.0(2.4$ $\pm 0.4) \mu \mathrm{m}$ wide. Three to four coils per polar filament. Uninucleate sporoplasm transversely elongate, extending into both shell valves.

Vegetative stages: Disporous, coelozoic trophozoites floating within gall bladder bile. Plasmodia mostly spherical to elongate and refractile, with numerous granules and inner generative cells ranging in size from 5 to $20 \mu \mathrm{m}$.

$\mathrm{T}$ y p e h o s t: Clinus cottoides Valenciennes, 1836 - endemic to South Africa from the Olifants River mouth on the west coast to the Kei River mouth on the southeast coast.

T y p e 1 o c a 1 i t y : De Hoop Nature Reserve (342's, $\left.20^{\circ} 30^{\prime} \mathrm{E}\right)$, South Africa.

Site of infection: Gall bladder.

Prevale nce : $59 \%(26 / 44)$

E t y m o l o g y : Named after the type host species.

P h o t o - r e f e r e n c e : Deposited in the National Museum Bloemfonteins' Parasite Collection; reference number: NMBP 300.

\section{Remarks}

Ceratomyxa cottoidii is possibly the same species collected from gall bladders of intertidal fishes in Table Bay and False Bay in South Africa by Fantham (1930). The species descriptions by Fantham (1930) unfortunately do not contain sufficient descriptive information and illustrations, making it impossible to distinguish them from other similar species and as a result are considered nomina nuda. Amongst the other Ceratomyxa species found infecting African marine fishes, C. cottoidii closely resembles $C$. australis Gaevskaya et Kovaleva, 1979 (Gaevskaya and Kovaleva 1979). The spores of $C$. australis are, however, smaller and have a shorter spore length (Table 2) giving them a narrower appearance compared to the more broadly rounded spores of $C$. cottoidii. The polar capsules of C. australis are also more teardrop-shaped compared to the almost spherical polar capsules of $C$. cottoidii. Ceratomyxa cottoidii resembles C. lagocephali Kpatcha, Diebakate, Faye et Toguebaye, 1996 described from the gall bladder of Lagocephalus laevigatus off the coast of Senegal by Kpatcha et al. (1996b). The spores of C. lagocephali are more broadly crescent-shaped than $C$. cottoidii. Furthermore, the spherical polar capsules of C. lagocephali are larger than the smaller, almost spherical polar capsules of $C$. cottoidii. Compared with species from around the world, C. cottoidii resembles C. arripica described from Tasmania by Su and White (1994). The spores of $C$. arripica are, however, smaller than C. cottoidii. Furthermore, the spores of $C$. arripica have a very prominent convex anterior, tapering to two equally rounded ends, unlike the spores of $C$. cottoidii, which have more broadly rounded ends, with one end occasionally tapering to a greater degree. Ceratomyxa cottoidii has some morphological similarities with $C$. buri Yokoyama et Fukuda, 2001 described from the gall bladder of Seriola quinqueradiata in Japan by Yokoyama and Fukuda (2001). The spores of C. buri have the same average spore length, but have a narrower spore width than the spores of $C$. cottoidii. Ceratomyxa cottoidii differs from $C$. dehoopi in having more broadly arched spores as opposed to the more narrow spores of C. dehoopi. Ceratomyxa dehoopi also has rounded polar capsules which differ from the teardrop-shaped polar capsules of $C$. cottoidii.

\section{Ceratomyxa honckenii sp. $\mathrm{n}$.}

Figs. 11, 14

Spores ( $n=20$ live spores): Mature spores transversely elongate, very slightly crescent-shaped and broadly concave, $7.5-8.0(7.8 \pm 0.3) \mu \mathrm{m}$ long $\times 18.0$ $21.0(19.0 \pm 1.4) \mu \mathrm{m}$ wide. Shell valves smooth, equal in size, tapering to broadly rounded end while sutural line is straight with two almost spherical polar capsules situated medially. Polar capsules 3.0-3.2 $(3.1 \pm 0.1) \mu \mathrm{m}$ long $\times 3.0-3.1(3.0 \pm 0.04) \mu \mathrm{m}$ wide, with polar filaments that have two to three coils in each polar capsule. Uninucleate sporoplasm transversely elongate extending into each of two shell valves, almost filling entire spore cavity. 
Vegetative stages: Disporous spherical trophozoites observed floating within gall bladder bile. Trophozoites mostly transparent with refractile granules, ranging in size 5 to $20 \mu \mathrm{m}$.

T y p e ho s t: Amblyrhynchotes honckenii (Bloch, 1795)Indo-Pacific species.

T y p e 1 o c a 1 i t y : De Hoop Nature Reserve $\left(34^{\circ} 28^{\prime} \mathrm{S}\right.$, $\left.20^{\circ} 30^{\prime} \mathrm{E}\right)$, South Africa.

O t h e r 1 o c a 1 i t i e s : Jeffrey's Bay $\left(34^{\circ} 2.2^{\prime}\right.$ S, $\left.24^{\circ} 56.5^{\prime} \mathrm{E}\right)$, South Africa.

Site of infection: Gall bladder.

P r e v a 1 e n c e : De Hoop Nature Reserve, 58\% (7/12); Jeffrey's Bay, $50 \%(1 / 2)$.

E t y m o lo g y : Named after type host species.

P h o t o - r e f e r e n c e : Deposited in the National Museum Bloemfonteins' Parasite Collection; reference number: NMBP 301.

\section{Remarks}

Amongst the three Ceratomyxa species collected from the De Hoop Nature reserve, Ceratomyxa honckenii has the longest spore length and most box-like appearance. Morphologically the most similar African species is $C$. lagocephali, but this species has a relatively longer spore body length than $C$. honckenii (Kpatcha et al. 1996b) (Table 2), giving the spores of $C$. honckenii a narrower appearance than the broader spores of $C$. lagocephali. Another similar African species is $C$. acanthuri Kpatcha, Diebakate, Faye et Toguebaye, 1996 described from the gall bladder of Acanthurus monroviae in Senegal (Kpatcha et al. 1996b). Ceratomyxa acanthuri does, however, have a much longer spore length and narrower spore width (Table 2) than the slightly more transversely elongate spores of $C$. honckenii. Compared with species throughout the world, C. honckenii is similar to C. buri described from Japan by Yokoyama and Fukuda (2001). The spores of $C$. buri have a narrower spore width and are anteriorly more convex, compared to the broadly crescent-shaped spores of $C$. honckenii. The bile of $A$. honckenii individuals tended to be normally thick and dark green in colour, with the gall bladder linings being naturally thick. No abnormal discolouring or thickening of this organ was noted in the infected individuals.

\section{Henneguya clini sp. n.}

Figs. 15, 16, 22

Spores $(n=20$ live spores): Mature spores ovoid to spherical in valvular view and bi-convex in sutural view. Anterior and posterior ends equally rounded, spore body 9.0-11.0 $(10.0 \pm 0.6) \mu \mathrm{m}$ long $\times 7.0-8.5(7.9$ $\pm 0.4) \mu \mathrm{m}$ wide. Shell valves smooth, equal with wide sutural ridge. Two separate, very long, thin filiform caudal projections extending from posterior of spore. Total length of spores 43.0-46.0 $(44.6 \pm 2.0) \mu \mathrm{m}$. Two pyriform polar capsules in anterior of spore, 4.0-4.2 $(4.0 \pm 0.1) \mu \mathrm{m}$ long $\times 2.0-2.5(2.2 \pm 0.2) \mu \mathrm{m}$ wide. Four to five coils in polar filament. Binucleate sporoplasm situated directly behind two polar capsules, almost filling entire spore cavity.

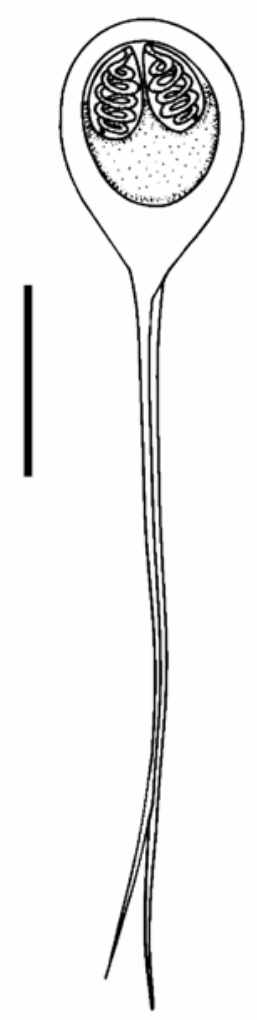

Fig. 15. Line drawing of live spore of Henneguya clini sp. n. from the gills of Clinus superciliosus collected from the Cape south coast, South Africa. Scale bar $=10 \mu \mathrm{m}$.

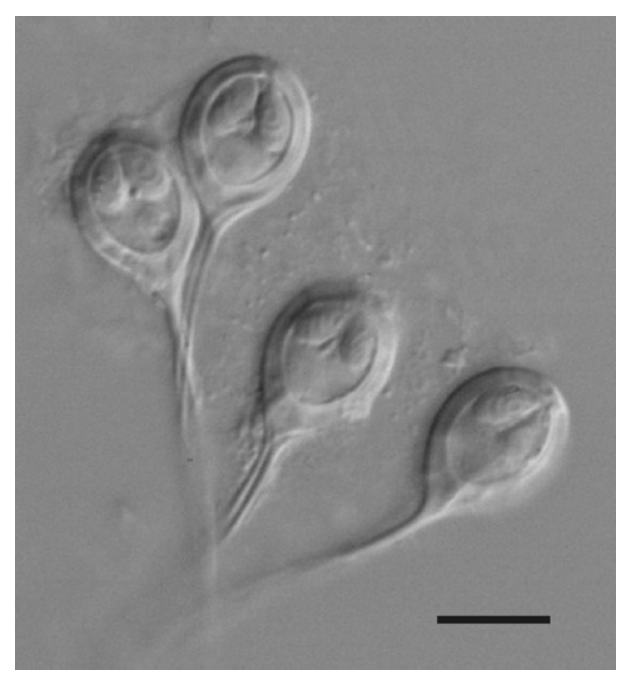

Fig. 16. Light micrograph of live spores of Henneguya clini sp. n. from the gills of Clinus superciliosus collected from the Cape south coast, South Africa. Scale bar $=10 \mu \mathrm{m}$.

Vegetative stages: Large histozoic polysporic plasmodia found within blood vessels of gills and gill arches. Plasmodia white, varying in shape and size, measuring 1 to $3 \mathrm{~mm}$ in length. 


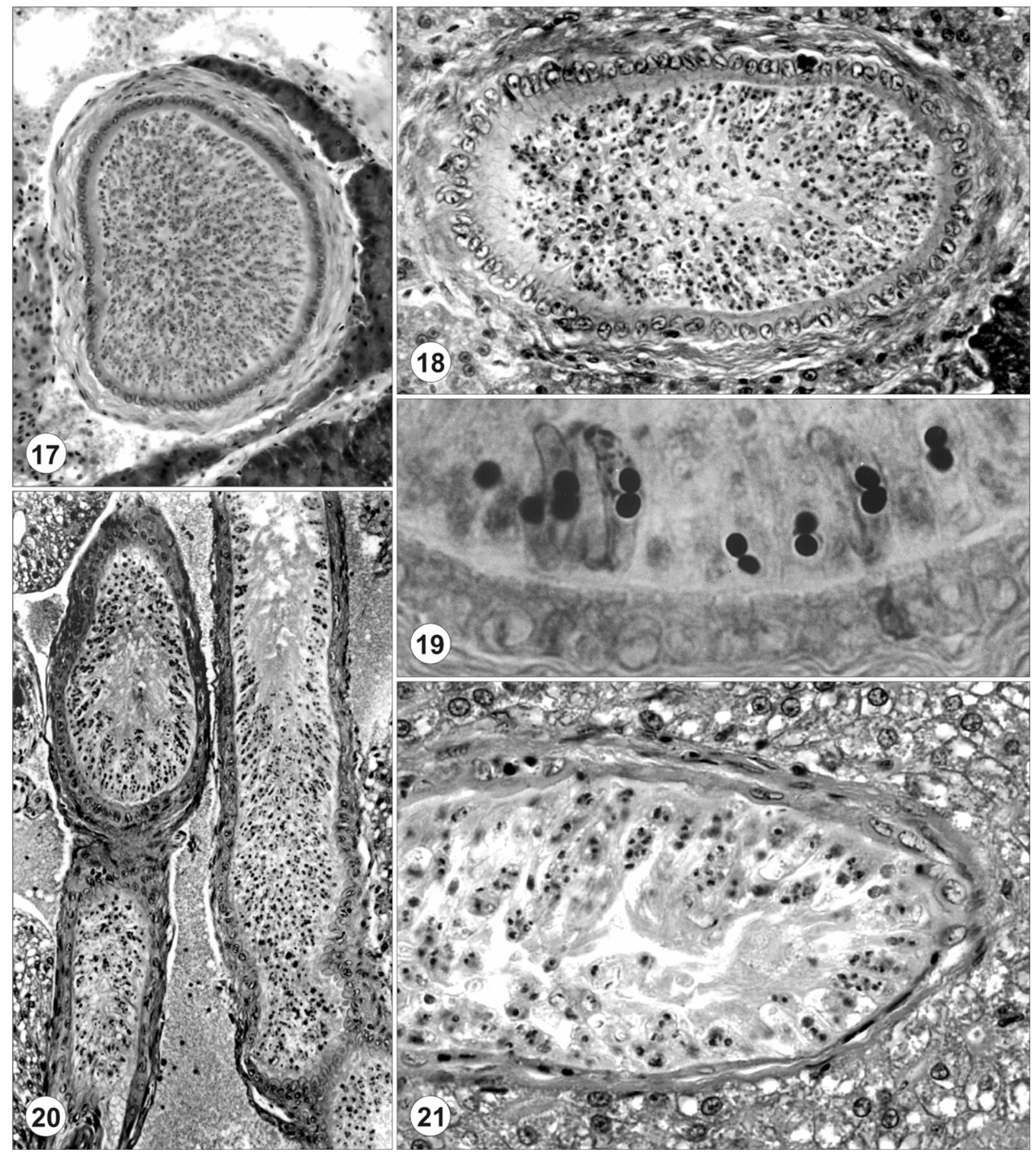

Figs. 17-21. Histological sections of fish organs infected with myxosporeans from the Cape south coast of South Africa. Figs. 17-19. Bile ducts of Clinus superciliosus showing Ceratomyxa dehoopi $\mathrm{sp}$. n. plasmodia and spores closely associated with epithelium. H\&E, $\times 290, \times 460$ and $\times 1,600$, respectively. Figs. 20, 21. Extrahepatic and intrahepatic bile ducts of $C$. superciliosus showing plasmodia and spores of Ceratomyxa cottoidii sp. $\mathrm{n}$. H\&E, $\times 250$ and $\times 560$, respectively.

T y p e host: Clinus superciliosus (Linnaeus, 1758).

T y p e 1 o c a 1 i t y : De Hoop Nature Reserve $\left(34^{\circ} 28^{\prime} \mathrm{S}\right.$, $\left.20^{\circ} 30^{\prime} \mathrm{E}\right)$, South Africa.

Other hosts at type locality: Clinus cottoides Valenciennes, 1836.
Other localities in type host: Jeffrey's Bay $\left(34^{\circ} 2.2^{\prime} \mathrm{S}, 24^{\circ} 56.5^{\prime} \mathrm{E}\right)$, South Africa.

Site of infection: Gills and gill arches.

P r e v a 1 e n c e : Clinus superciliosus, 1\% (1/92); Clinus cottoides, 2\% (1/44); at De Hoop Nature Reserve. Clinus superciliosus at Jeffrey's Bay, 2\% (1/38). 
Table 3. Henneguya Thélohan, 1892 species known from marine fishes along the African coast. Key to references: 1 - Bahri et al. (1996); 2 - Faye et al. (1997); 3 - Kpatcha et al. (1997).

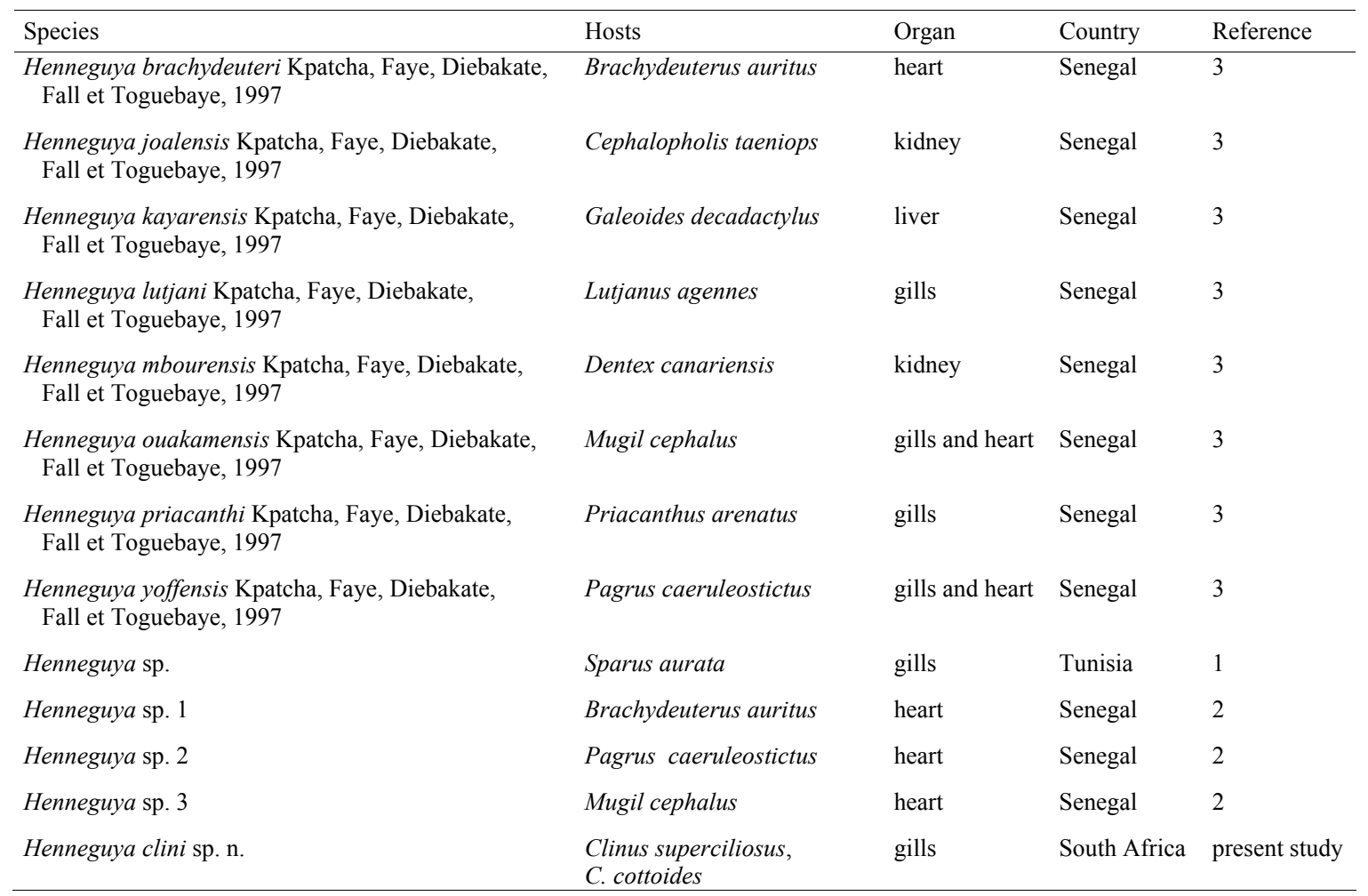

Table 4. Spore measurements (in $\mu \mathrm{m}$ ) of African marine Henneguya Thélohan, 1892 species, including those from the present study. Key: CL - caudal length;; PC - polar capsule; R - reference; SBL - spore body length; SBW - spore body width; TL total length. Key to references: 1 - Kpatcha et al. (1997); P - present study.

\begin{tabular}{|c|c|c|c|c|c|c|c|}
\hline Species & $\mathrm{TL}$ & SBL & $\mathrm{CL}$ & SBW & PC length & PC width & $\mathrm{R}$ \\
\hline Henneguya brachydeuteri & $\begin{array}{l}37.18 \pm 0.98 \\
(36.0-41.0)\end{array}$ & $\begin{array}{l}11.5 \pm 0.5 \\
(10.0-12.0)\end{array}$ & $\begin{array}{l}26.9 \pm 0.9 \\
(26-29)\end{array}$ & $\begin{array}{l}8.36 \pm 0.75 \\
(7-9)\end{array}$ & $\begin{array}{l}4.33 \pm 0.5 \\
(4.0-5.0)\end{array}$ & $\begin{array}{l}2.6 \pm 0.5 \\
(2.0-3.0)\end{array}$ & 1 \\
\hline Henneguya joalensis & $\begin{array}{l}44.81 \pm 0.2 \\
(44.5-45.0)\end{array}$ & $\begin{array}{l}8.9 \pm 0.1 \\
(8.5-9.0)\end{array}$ & $\begin{array}{l}35.25 \pm 0.97 \\
(34.0-36.0)\end{array}$ & $\begin{array}{l}6.37 \\
(6.0-7.0)\end{array}$ & $\begin{array}{l}\text { Smaller: } \\
3.73 \pm 1.18 \\
(3.4-4.5) \\
\text { Larger: } \\
4.78 \pm 0.45 \\
(4.5-5.5)\end{array}$ & $\begin{array}{l}\text { Smaller: } \\
1.86 \pm 0.09 \\
(1.8-2.0) \\
\text { Larger: } \\
2.53 \pm 0.21 \\
(2.25-3.0)\end{array}$ & 1 \\
\hline Henneguya kayarensis & $\begin{array}{l}54.70 \pm 0.83 \\
(52.0-56.5)\end{array}$ & $\begin{array}{l}8.41 \pm 0.65 \\
(7.0-9.0)\end{array}$ & $\begin{array}{l}46.29 \pm 0.98 \\
(45.0-47.5)\end{array}$ & $\begin{array}{l}6.6 \pm 0.41 \\
(6.0-7.0)\end{array}$ & $\begin{array}{l}4.32 \pm 0.19 \\
(4.0-4.5)\end{array}$ & $\begin{array}{l}2.36 \pm 0.11 \\
(2.25-2.5)\end{array}$ & 1 \\
\hline Henneguya lutjani & $\begin{array}{l}49.96 \pm 0.98 \\
(47.25-50.4)\end{array}$ & $\begin{array}{l}11.86 \pm 0.6 \\
(11.25-13.0)\end{array}$ & $\begin{array}{l}37.22 \pm 0.98 \\
(36.0-38.25)\end{array}$ & $\begin{array}{l}7.29 \pm 0.73 \\
(6.0-8.0)\end{array}$ & $\begin{array}{l}3.84 \pm 0.58 \\
(3.0-4.5)\end{array}$ & $\begin{array}{l}2.96 \pm 0.44 \\
(2.25-3.5)\end{array}$ & 1 \\
\hline Henneguya mbourensis & $\begin{array}{l}29.62 \pm 0.99 \\
(28.0-33 .)\end{array}$ & $\begin{array}{l}10.26 \pm 0.44 \\
(10.0-11.0)\end{array}$ & $\begin{array}{l}20.66 \pm 0.99 \\
(20.0-22.5)\end{array}$ & $\begin{array}{l}7.98 \pm 0.98 \\
(6.5-9.0)\end{array}$ & $\begin{array}{l}4.78 \pm 0.5 \\
(3.5-5.0)\end{array}$ & $\begin{array}{l}2.4 \pm 0.5 \\
(2.0-3.5)\end{array}$ & 1 \\
\hline Henneguya ouakamensis & $\begin{array}{l}20.86 \pm 1.47 \\
(16.0-24.0)\end{array}$ & $\begin{array}{l}10.9 \pm 0.57 \\
(9.0-13.0)\end{array}$ & $\begin{array}{l}9.9 \pm 1.36 \\
(6.0-14.0)\end{array}$ & $\begin{array}{l}9.0 \pm 0.44 \\
(5.0-9.0)\end{array}$ & $\begin{array}{l}3.78 \pm 0.48 \\
(3.0-4.0)\end{array}$ & $\begin{array}{l}2.43 \pm 0.42 \\
(2.0-3.0)\end{array}$ & 1 \\
\hline Henneguya priacanthi & $\begin{array}{l}39.74 \pm 0.99 \\
(36.5-41.0)\end{array}$ & $\begin{array}{l}9.18 \pm 0.22 \\
(9.0-9.5)\end{array}$ & $\begin{array}{l}28.12 \pm 0.1 \\
(22.5-31.5)\end{array}$ & $\begin{array}{l}7.32 \pm 0.5 \\
(6.5-8.0)\end{array}$ & $\begin{array}{l}2.16 \pm 0.1 \\
(2.0-2.5)\end{array}$ & $\begin{array}{l}1.34 \pm 0.1 \\
(1.0-2.0)\end{array}$ & 1 \\
\hline Henneguya yoffensis & $\begin{array}{l}46.18 \pm 0.36 \\
(37.0-50.0)\end{array}$ & $\begin{array}{l}13.38 \pm 0.19 \\
(12.0-15.0)\end{array}$ & $\begin{array}{l}32.13 \pm 0.27 \\
(24.0-36.0)\end{array}$ & $\begin{array}{l}9.13 \pm 0.31 \\
(8.0-11.0)\end{array}$ & $\begin{array}{l}3.47 \pm 0.19 \\
(3.0-4.0)\end{array}$ & $\begin{array}{l}2.30 \pm 0.13 \\
(2.0-3.0)\end{array}$ & 1 \\
\hline Henneguya clini sp. n. & $\begin{array}{l}43.0-46.0 \\
(44.6 \pm 2.0)\end{array}$ & $\begin{array}{l}9.0-11.0 \\
(10.0 \pm 0.6)\end{array}$ & $\begin{array}{l}34.0-35.0 \\
(34.0 \pm 1.4)\end{array}$ & $\begin{array}{l}7.0-8.5 \\
(7.9 \pm 0.4)\end{array}$ & $\begin{array}{l}4.0-4.2 \\
(4.0 \pm 0.1)\end{array}$ & $\begin{array}{l}2.0-2.5 \\
(2.2 \pm 0.2)\end{array}$ & $\mathrm{P}$ \\
\hline
\end{tabular}




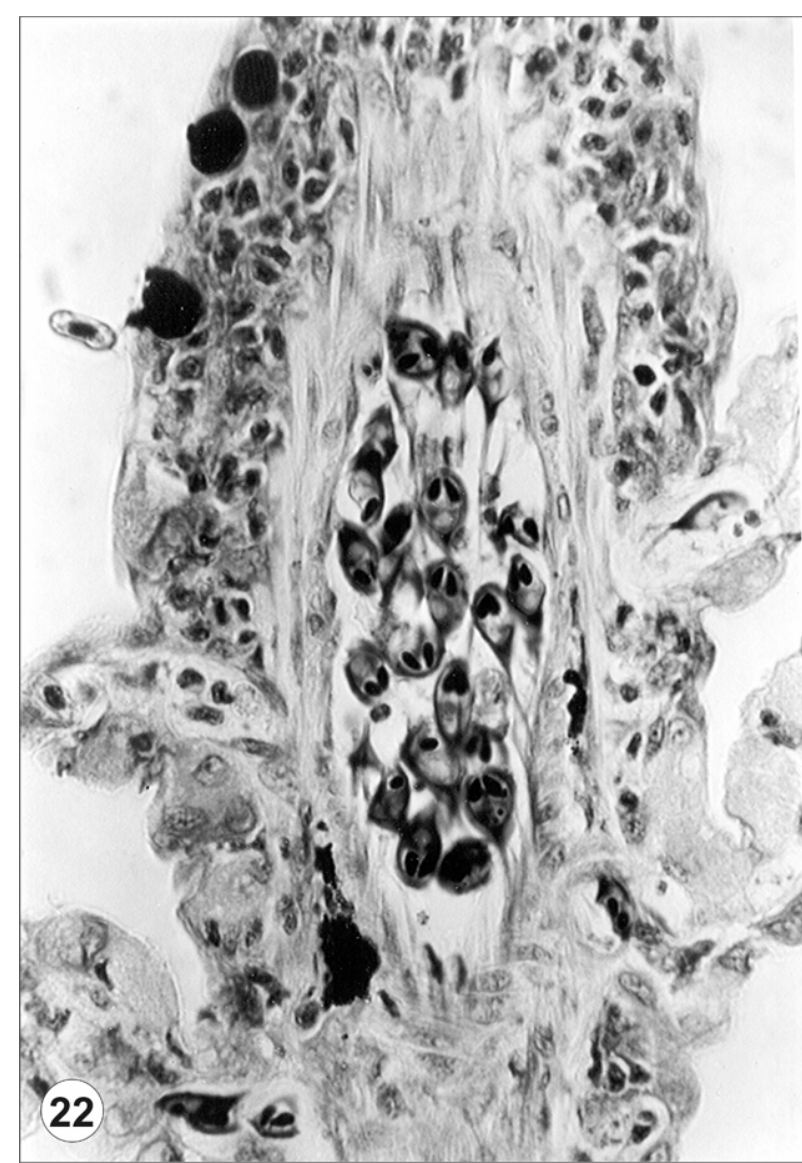

Fig. 22. Histological section of Clinus superciliosus gills showing spores of Henneguya clini sp. n. released from mature plasmodium. Giemsa stain, $\times 900$.

\section{Remarks}

Henneguya clini does not conform to the description of any of the species listed in Eiras's (2002) comprehensive world-wide synopsis of the species of the genus Henneguya. All eight African marine Henneguya species described from fishes along the Senegalese coast by Kpatcha et al. (1997) (Table 3) have very similar morphological appearances. One very prominent characteristic that they all exhibit is a very wide sutural ridge. The same characteristic was found in H. clini.

Although all the species described from Senegal are very similar to $H$. clini, they each exhibit one or more distinguishing characteristics. The spores of $H$. brachydeuteri from the heart of Brachydeuterus auritus are generally shorter in total length (Table 4) and appear to have a much wider sutural ridge than $H$. clini. Henneguya joalensis from the kidney of Cephalopholis taeniops has the same average total spore length, but has a shorter spore body length (Table 4) compared to that of $H$. clini. The spores of $H$. kayarensis from the liver of Galeoides decadactylus are much longer in total spore length and generally have a smaller spore body (Table 4) than $H$. clini. Henneguya lutjani from the gills of Lutjanus agennes also has much longer spores that are generally larger than those of $H$. clini. The spores of $H$. mbourensis from the kidney of Dentex canariensis are much shorter in total length than the spores of $H$. clini. Morphologically the spores of $H$. ouakamensis from the gills of Mugil cephalus are most distinct from $\mathrm{H}$. clini. These are much shorter and have an almost spherical spore body, compared with the more elongate spores of $H$. clini that do not have a totally spherical spore body. Henneguya priacanthi from the gills of Priacanthus arenatus is most similar to $H$. clini, but has a relatively shorter total spore length and generally smaller polar capsules (Table 4). The spores of $H$. yoffensis from the gills and heart of Sparus caeruleostictus have the same average total spore length, but have a larger spore body (Table 4) than H. clini.

\section{Pathogenicity}

Histological sections of infected gill arches revealed that the massive plasmodia severely distorted the entire gill arch and many of the gill lamellae. Although none of the fish showed infections with more than half of the gills appearing severely distorted, the large plasmodia did compress many of the smaller gill filaments in the infected individuals. These fish spend their entire lives in intertidal pools, which are subjected to daily variations in oxygen concentrations, salinity and temperature as a result of tidal movements. It is possible that such infections affect the respiratory function of gills. This could potentially have an adverse effect on the ability of infected individuals to survive in harsh tidal pool environments, particularly during low tides when oxygen concentrations in intertidal pools drop dramatically.

Acknowledgements. This study was funded by National Research Foundation (NRF) of South Africa. We would also like to thank the Canon Collins Trust for Southern African Education for additional funding as well as Prof. Angela Davies (Kingston University, UK) for her invaluable assistance with histology and general scientific input. Many thanks also to CapeNature for the use of their facilities at De Hoop Nature Reserve, South Africa. Scanning electron micrographs were obtained at the Centre for Confocal and Electron Microscopy, University of the Free State, Bloemfontein. The participation of I.D. in this study was financially supported by research projects of the Institute of Parasitology, Academy of Sciences of the Czech Republic (Z60220518 and LC 522) and Faculty of Science, University of South Bohemia (MSM 6007665801). 


\section{REFERENCES}

ALI M.A. 2000: Ortholinea basma n. sp. (Myxozoa: Myxosporea) from the Agile Klipfish Clinus agilis (Teleostei: Clinidae). Light and scanning electron microscopy. Eur. J. Protistol. 36: $100-102$.

Alvarez-Pellitero P.E., SituÁ-Bobadilla A. 1993: Ceratomyxa spp. (Protozoa: Myxosporea) infections in wild and cultured sea bass, Dicentrarchus labrax, from the Spanish Mediterranean area. J. Fish Biol. 42: 889-901.

BAHRi S., HASSINE O.K.B., MARQues A. 1996: Henneguya sp. (Myxosporea, Bivalvulida) infecting the gills of wild gilthead sea bream Sparus aurata L., from the coast of Tunisia. Bull. Eur. Assoc. Fish Pathol. 16: 51-53.

BAHRI S., MARQUÉS A. 1996: Myxosporean parasites of the genus Myxobolus from Mugil cephalus in Ichkeul Lagoon, Tunisia: description of two new species. Dis. Aquat. Org. 27: 115-122.

BAHri S., MARQuÉs A., COSTE F., BouiX G., Hassine O.K.B. 1995: Presence of cutaneous myxosporidian in Tunisian Mugil cephalus (Linnaeus, 1758). Bull. Eur. Assoc. Fish Pathol. 15: 54-57.

BRANCH G.M., GRIFFITHS C.L., BRANCH M.L., BECKLEY L.E. 1994: Two Oceans: A Guide to the Marine Life of Southern Africa. First edition. David Philip Publishers, Claremont, South Africa, $360 \mathrm{pp}$.

DAVIES R., BEYERS E. 1947: A protozoal disease of South African trawled fish and its routine detection by fluorescence. Nature 159: 714 .

Diebakate C., Fall M., FAye N., Toguebaye B.S. 1999: Unicapsula marquesi n. sp. (Myxosporea, Multivalvulida) parasite des branchies de Polydactylus quadrifilis (Cuvier, 1829) (Poisson, Polynemidae) des côtes sénégalaises (Afrique de l'Ouest). Parasite 6: 231-235.

DUBINA V.R., ISAKOV L.S. 1976: New species of myxosporidians from the gall bladder of bathial fishes. Parazitologiya 10: $556-560$.

EIRAS J.C. 2002: Synopsis of the species of the genus Henneguya Thélohan, 1892 (Myxozoa: Myxosporea: Myxobolidae). Syst. Parasitol. 52: 43-54.

Fall M., Kpatcha T.K., Diebakate C., Faye N., Toguebaye B.S. 1997: Observations sur des myxosporidies (Myxozoa) du genre Myxobolus parasites de Mugil cephalus (Poisson, Téléostéen) du Sénégal. Parasite 4: 173-180.

FANTHAM H.B. 1919: Some parasitic protozoans found in South Africa, II. S. Afr. J. Sci. 16: 185-191.

FANTHAM H.B. 1930: Some parasitic protozoans found in South Africa, XIII. S. Afr. J. Sci. 27: 376-390.

Faye N., Kpatcha T.K., Diebakate C., Fall M., Toguebaye B.S. 1999: Gill infections due to myxosporean (Myxozoa) parasites in fishes from Senegal with descriptions of Myxobolus hani sp. n. Bull. Eur. Assoc. Fish Pathol. 19: 14-16.
FAyE N., KPATCHA T.K., FAll M., TOGUEBAyE B.S. 1997: Heart infections due to myxosporean (Myxozoa) parasites in marine and estuarine fishes from Senegal. Bull. Eur. Assoc. Fish Pathol. 17: 115-117.

Gaevskaya A.V., Kovaleva A.A. 1979: Two new species of Myxosporidia Davisia donecae n. sp. and Ceratomyxa australis n. sp. from the horse mackerel in the southeastern Atlantic. Russ. J. Mar. Biol. 3: 80-83.

GILCHRIST J.D.F. 1924: A protozoal parasite Chloromyxum thyrsites sp. n. of the Cape sea fish, the "snoek" (Thyrsites atun, Euplin). Trans. R. Soc. S. Afr. 11: 263-273.

KPATCHA T.K., DiebaKate C., FAYE N., TOGUEBAyE B.S. 1996b: Quelques nouvelles espèces de Myxosporidies, du genre Ceratomyxa Thélohan, 1895 parasites des poissons marins du Sénégal, Afrique de l'Ouest. Parasite 3: 223-228.

KPATCha T.K., DiebaKate C., FAYE N., TOGUEBAYE B.S. 1999: Light and electron microscopic observations on Kudoa boopsi sp. n. (Myxosporea: Kudoidae), a gill parasite of Boops boops (Pisces: Teleostei: Sparidae) from Coasts of Senegal (West Africa). Acta Protozool. 38: 317-321.

Kpatcha T.K., Diebakate C., Toguebaye B.S. 1996a: Myxosporidies (Myxozoa, Myxosporea) des genres Sphaeromyxa Thélohan, 1892, Myxidium Bütschli, 1882, Zschokkella Auerbach, 1910, Bipteria Kovaljova, Zubtchenko and Krasin, 1983 et Leptotheca Thélohan, 1895 parasites des poissons des côtes sénégalaises (Afrique de l'Ouest). J. Afr. Zool. 110: 309-319.

Kpatcha T.K., Faye N., Diebakate C., Fall M., Toguebaye B.S. 1997: Nouvelles espèces d'Henneguya Thélohan, 1895 (Myxozoa, Myxosporea) parasites des poisons marins du Sénégal: étude en microscopie photonique et électronique. Ann. Sci. Nat. Zool. 18: 81-91.

LOM J., ARTHUR J.R. 1989: A guideline for the preparation of species descriptions in Myxosporea. J. Fish Dis. 12: 151-156.

Schulman S.S., KovaleVA A.A., Dubina V.R. 1979: New Myxosporidians from fishes of the Atlantic coast of Africa. Parazitologiya 13: 71-79.

SitjÁ-Bobadilla A., PAlenzuela O., Álvarez-Pellitero P. 1995: Ceratomyxa sparusaurati n. sp. (Myxosporea: Bivalvulida), a new parasite from cultured gilthead seabream (Sparus aurata L.) (Teleostei: Sparidae): light and electron microscopic description. J. Eukaryot. Microbiol. 42: 529-539.

Su X.-G., White R.W.G. 1994: New myxosporean (Myxozoa: Myxosporea) from marine fishes of Tasmania, Australia. Acta Protozool. 33: 251-259.

YOKOYAMA H., FUKUDA Y. 2001: Ceratomyxa seriolae n. sp. and C. buri n. sp. (Myxozoa: Myxosporea) from the gall-bladder of cultured yellowtail Seriola quinqueradiata. Syst. Parasitol. 48: 125-130.

Accepted 18 June 2007 